\title{
The Impact of Work Stress on Turnover Intention in Indonesia: Is There A Mediation from Employee' Job Satisfaction?
}

\author{
Ary Ferdian ${ }^{1}$, Bachruddin Saleh Luturlean ${ }^{2}$, Khairani Ditha Zhafira ${ }^{1}$, Nabilla Kalvina Izumi ${ }^{1}$ \\ ${ }^{1}$ School of Economics \& Business, Telkom University, Jl Telekomunikasi, 40257, Bandung, Indonesia \\ ${ }^{2}$ School of Communications \& Business, Telkom University, J1 Telekomunikasi, 40257, Bandung, Indonesia
}

\section{ABSTRACT}

Objective - This paper aims to investigate the impact of the work stress on job satisfaction and employee turnover among the employees in Bandung.

Methodology/Technique - The study is conducted between January - April 2019 in a private company in Bandung. We distributed questionnaire to 400 participants through the human resource department in each company and obtained 216 valid and usable participants. We used SPSS software to analyze the regression and Macro Process to identify the mediation role.

Findings - The findings reveal a direct effect of work stress on both job satisfaction and turnover intention, and there was also direct significant relationship between job satisfaction and turnover intention. Job satisfaction plays a mediatory role in the relationship between work stress and turnover intention. The results indicate the strategic policies of HR manager that they should consider stress and satisfaction when confront with high turnover. To identify the turnover leave, managers need to conduct routine survey regarding the employee intention.

Novelty - The study uses participants from Indonesia which is considered as a collectivist culture which is still limited; thus our contribution is to provide wider perspective regarding the relationship model of work stress, satisfaction, and turnover intention. Both academics and practitioners could use the results of this study as a basis for future research.

Type of Paper: Empirical

Keywords: Work Stress; Job Satisfaction; Turnover Intention.

Reference to this paper should be made as follows: Ferdian, A; Luturlean; B.S; Zhafira, K.D; Izumi, N.K. (2020). The Impact of Work Stress on Turnover Intention in Indonesia: Is There A Mediation from Employee' Job Satisfaction? J. Mgt. Mkt. Review, 5(1) 31 - 40 https://doi.org/10.35609/jmmr.2020.5.1(3)

JEL Classification: M12, M19.

\section{Introduction}

The European Union General Data Protection Regulation, regulating the processing and use of personal data in the EU, forces companies to review and upgrade their existing policies, procedures, and practices to ensure compliance (Rodríguez-Doncel et. al., 2016).

\footnotetext{
* Paper Info: Revised: January 10, 2020

Accepted: March 30, 2020

* Corresponding author: Ary Ferdian

E-mail: partono67@gmail.com

Affiliation: School of Economics \& Business, Telkom University, J1 Telekomunikasi, 40257, Indonesia
} 
Business organizations either in service or product markets are determined to achieve their goals and continue to grow. They need to be organized and manage their valuable resources. One important asset is employees. Human resources have conceptual, analytical, and strategic ideas that can be optimized for managing other resources. Failure to take care of employees will result in the loss of the opportunity to grow. Organizations that have difficulty retaining their employees will experience obstacles in pursuing their target (Hughes et. al., 2010). Gyensare et. al. (2015) states that the most difficult challenge confronting most businesses in the 21st century is the issues of employee turnover, and turnover intention. A Report from the Work Institute (2018) states that 33\% of employees will leave their job each year by 2020 .

Turnover intention describes an individual's own thoughts that they might leave the organizations at some point of time in the near future. Chen et. al. (2014) explains turnover intention as turnover plan. Turnover intention is different than the actual turnover. The latter refers to the employee's actual behavior when they decide to end the employment. Turnover intention is a behavioral tendency or thought to leave their work organization. This intention might lead to actual turnover. It is important to focus the study on turnover intention as it is the driver for actual turnover. The negative effect of turnover has been the focus of top management in almost every industry because it is one of the most expensive and difficult workforce challenges (Moynihan \& Pandey, 2008). Therefore, determining the antecedents of employee turnover intention has been an ongoing goal of both employers and researchers (Park \& Shaw, 2013). This is confirmed by the results of studies by Morneau Shepell (2018) that employees are still a top concern for management. Boss (2018) also argues that employee turnover rates have reached the highest level in the last 10 years.

The findings of many previous studies conclude that job satisfaction (Yucel \& Bektas, 2012), affective commitment (Albrecht \& Andreeta, 2011), rewards and work-life balance (Cao et. al., 2013), and perceived organizational support (Hussain \& Asif, 2012) are inversely related to employee turnover intention. Other factors that can influence the intention to leave but in positive way are work stress (Javed et. al., 2014), work life conflict (Sang et. al., 2009), and job demand (Babakus et. al., 2008). The purpose of this study is to test a relationships model between work stress, job satisfaction, and employee turnover intention in Indonesia. Organizations in this part of the Asian country also face similar challenges regarding employee turnover. Our study design also examines the mediation effect of job satisfaction.

The contribution of this study is to enhance the discussion regarding work stress and turnover intention from different cultures, in this case from Indonesia. Stress is an individual perception and is believed to have great variation between cultures. It will be interesting to identify employees work stress from various industries and to study its effect on work behavior. The result can be used by business organizations to develop better human resources and work related policies. In addition, academics may also refer to this study when discussing the relationship model of work stress, satisfaction, and turnover intention.

Section 1 of this paper provides the background and contribution of this study. Exploration regarding related literatures and hypotheses development is describe in Section 2. Section 3 explains how the data is collected, measure, and analyzed. The main ingredient for this study is in Section 4, which provides the results and discusses the findings. Finally, Section 5 will conclude the paper.

\section{Literature Review}

\subsection{Work Stress, Job Satisfaction, and Turnover Intention}

According to Robbins and Judge (2017), work stress is a dynamic condition whereby an individual faced with an opportunity, claim, or resource related to the interests of the individual and the results are considered important but have a level of uncertainty about them. This condition can cause psychological discomfort. Employees often experience high levels of work-related demands and are therefore exposed of stress and burnout. Demanding supervisors, long work-hour, unfriendly work environment, higher target/goals, and demanding customers are some of the most common situations faced by employees. Employee work stress 
needs to be well managed because it can harm the individual and organization. Gibson et. al (2012) explains the behavioral impact of work stress including satisfaction, performance, absenteeism, turnover, accidents, drug abuse, and health service claims. Stress also has a cognitive impact which includes the inability to make decisions, frustration, reduced concentration, apathy, and forgetfulness. Furthermore, stress will have impact on individual physiological effects in terms of increased blood pressure, high cholesterol, and coronary heart disease.

Schermerhorn et. al. (2012) defines job satisfaction as employee's positive or negative feeling toward their job, co-workers, supervisor, and their work environment. Employee job satisfaction will increase if they experience positive feelings regarding these work factors. Organizations are concerned about maintaining high levels of job satisfaction because of the various consequences such as higher productivity, increased customer loyalty, low absenteeism and turnover, safety performance, and life satisfaction (DuBrin, 2019).

Snell and Bohlander (2013) define it as the movement of employees out of the company. Meanwhile, the term Turnover Intention (TI) is explained by Branham (2012) as a tendency for employee attitudes to look for new opportunities outside their current organization. TI is different from turnover because it is concerned with the tendency (intention), not actual resignation. By understanding TI, organizations can identify the level of employee intentions to quit and find new jobs within a certain period of time. In this sense, it contains an element of intention which means that employees resign because of their own desires. Employee turnover is considered as negative and costly for the organization. Employee turnover can cost organizations millions of dollars (Scandura, 2019). Managers must aware of the various antecedents of TI such as job stress, job satisfaction, organizational commitment, leadership style, and organizational justice (Gyensare et. al., 2015; Griffeth et. al., 2000; Siddiqui \& Jamil, 2015; Kaur et. al., 2013).

\subsection{The Relationship Between Work Stress, Job Satisfaction and Turnover Intention}

Work stress levels are believed to have an impact on job satisfaction. Research in various industries confirms the view regarding the inverse correlation between job stress and job satisfaction. This relationship is supported by previous studies from Malik et. al. (2011), Terera and Ngirande (2014), Venkataraman and Ganapthi (2013), Troesch and Bauer (2017), and Tziner et. al. (2015). Studies from Pakistan, Israel, Switzerland, and South Africa agree that work stress has a significant and negative relationship with job satisfaction. Employees who experience higher stress levels will have less satisfaction at work.

Most studies that address the relationship between work stress and turnover intention found a significant and positive relationship. Employees with higher work stress tend to develop greater intentions to quit. Studies in Pakistan found a strong correlation between work stress and turnover intention (Javed et. al., 2014). Studies in Turkey, Thailand, and South Korea found a moderate correlation (Chung et. al., 2017; Demiral, 2018).

Employees who perceive that the company gives attention to their well-being will provide positive returns. One positive feedback is that they stay longer in the organization. Robbins and Judge (2017) corroborate the statement that unhappy employees will drive negative responses such as leaving the organization. Most behavioral studies which examine the relationship between job satisfaction and turnover intention found a significant and negative correlation. Oosthuizen et. al. (2016) in South Africa, Jaramilo et. al. (2006) in the USA, Ang et. al. (2013) in Australia, and Mihelic (2014) in Slovenia found a moderate to strong negative correlation.

Based on the above, the following hypotheses are proposed:

H1: Work stress will have significant and negative effect on job satisfaction.

H2: Work stress will have significant and positive effect on turnover intention.

H3: Job satisfaction will have significant and negative effect on turnover intention. 


\subsection{Mediation Model of Job Satisfaction}

Job satisfaction has often functioned as a mediator as evidenced in scientific work. Nasra and Heilbrunn (2015) investigate the mediation of job satisfaction in the relationship of transformational leadership and organizational citizenship behavior. Fried et. al. (2008) examine the mediation role between work stress and performance. A study related with the mediating role of job satisfaction in the causal relationship of work stress and TI found a significant correlation (Fried et. al., 2008; Chung et. al., 2017). Based on the above, the following hypothesis is proposed:

H4: Job satisfaction will have mediation role in the relationship of work stress and turnover intention.

\section{Research Methodology}

\subsection{Participants}

A total of 400 questionnaires were sent out via human resources departments in 8 organizations in Bandung. The cover letter described the objectives of the study. The participants consist of employees working with the same organization for more than 1 year. 216 participant responses were usable for this study resulting in an overall response rate of 54\%. The participant demographic profiles are displayed in Table 1.

Table 1. Demographic Characteristics

\begin{tabular}{|c|c|c|c|c|c|c|c|}
\hline $\begin{array}{c}\text { Characteristi } \\
\text { c }\end{array}$ & Category & $\begin{array}{c}\text { Numbe } \\
\mathbf{r}\end{array}$ & $\begin{array}{c}\text { Percentag } \\
\text { e }\end{array}$ & $\begin{array}{c}\text { Characteristi } \\
\text { c }\end{array}$ & Category & $\begin{array}{c}\text { Numbe } \\
\mathbf{r}\end{array}$ & $\begin{array}{c}\text { Percentag } \\
\text { e }\end{array}$ \\
\hline \multirow{4}{*}{ Education } & High School & 95 & $53.4 \%$ & \multirow{6}{*}{ Age } & $<25$ years & 39 & $21.9 \%$ \\
\hline & Diploma & 39 & $21.9 \%$ & & 25 - 30 years & 22 & $12.4 \%$ \\
\hline & $\begin{array}{c}\text { Under } \\
\text { Graduate }\end{array}$ & 75 & $42.1 \%$ & & $\begin{array}{c}>30-35 \\
\text { years }\end{array}$ & 34 & $19.1 \%$ \\
\hline & Post Graduate & 7 & $3.9 \%$ & & $\begin{array}{c}>35-40 \\
\text { years }\end{array}$ & 39 & $21.9 \%$ \\
\hline \multirow{5}{*}{ Tenure } & $<1$ years & 18 & $10.1 \%$ & & $\begin{array}{c}>40-45 \\
\text { years }\end{array}$ & 51 & $28.7 \%$ \\
\hline & 1 - 3 years & 36 & $20.2 \%$ & & $\begin{array}{c}>45-50 \\
\text { years }\end{array}$ & 18 & $10.1 \%$ \\
\hline & $>3-5$ years & 13 & $7.3 \%$ & \multirow{5}{*}{ Position } & $>50$ years & 13 & $7.3 \%$ \\
\hline & $>5-10$ years & 21 & $11.8 \%$ & & Officer & 165 & $92.7 \%$ \\
\hline & $>10$ years & 128 & $71.9 \%$ & & Supervisor & 24 & $13.5 \%$ \\
\hline \multirow{2}{*}{ Gender } & Male & 71 & $39.9 \%$ & & Manager & 27 & $15.2 \%$ \\
\hline & Female & 145 & $81.5 \%$ & & & & \\
\hline
\end{tabular}

\subsection{Measurement and Analysis}

Job satisfaction is measured using 20 items developed by Prasetio et. al. (2019). The results of the Cronbach alpha is $>.07$ (.928). Sample items were 'I have the authority to do my work independently' and 'My job allowed me to perform various activities'. The work stress and turnover intention scale was developed based on the work of Elci et. al. (2012). The work stress scale consists of 8 items with a Cronbach alpha of .750 and sample items were 'I feel Exhausted after work' and 'My Work demands a lot of my time and energy'. Turnover intention was measured with 6 items and the Cronbach alpha is .810. Sample items 
were 'Often thinking of quitting from work' and 'Actively look for better employment opportunities'. Participants were asked to choose 1 of 6 alternatives ranging from $1=$ very disagree and $6=$ very agree.

After the raw data was codified, the analysis using SPSS V. 21 and Macro Process was conducted. We obtained regression results for each causal relationship and, using a bootstrap approach, we determined the mediation. First, we put the data in the SPSS with Macro Process installed. Next, regression analysis was conducted using model 6 in the Macro Process Menu. This provides the results regarding regression and also the mediation analysis. This method avoids the normality assumption. The application of bootstrapping confidence intervals will reveal whether there is mediation or not. We apply the 95\% confidence interval (CI) with 5.000 bootstraps. Bootstrap was used because this method does not require the normality assumptions related to sample distribution through the application of bootstrapping confidence intervals (Preacher et. al., 2007). Job satisfaction has a mediation role in the relationship if the value of the Upper-level and Lowerlevel Confidence Interval do not contain 0. Ghadi et. al. (2013) also states that researchers show that the bootstrapping approach is a more valid and powerful method for testing mediation effects.

\section{Results}

The correlation results are shown in Table 2 and reveal that work stress is significantly and strongly related to turnover intention $(\mathrm{r}=0.610)$. However, it has weak negative correlation with job satisfaction $(\mathrm{r}=-$ $.265)$. On the other hand, job satisfaction also has a weak correlation with turnover intention $(\mathrm{r}=-.360)$.

Table 2. Correlations Between Constructs

\begin{tabular}{|c|c|c|c|c|c|c|c|c|c|c|c|}
\hline & & Mean & Std. Deviation & 1 & 2 & 3 & 4 & 5 & 6 & 7 & 8 \\
\hline 1 & Age & 3.4583 & 1.52441 & 1 & & & & & & & \\
\hline 2 & Education & 1.9722 & .95925 & -.115 & 1 & & & & & & \\
\hline 3 & Tenure & 3.9491 & 1.44099 & $.877^{* *}$ & $\overline{-176 * *}^{* *}$ & 1 & & & & & \\
\hline 4 & Position & 1.3611 & .69494 & $.339^{* *}$ & $.559^{* * *}$ & $.279^{* * *}$ & 1 & & & & \\
\hline 5 & Workhour & 1.2731 & .44661 & .054 & $.441^{* *}$ & . 043 & $\begin{array}{c}.535^{*} \\
*\end{array}$ & 1 & & & \\
\hline 6 & Stress & 3.4622 & .84657 & $.225^{* *}$ & $.338^{* * *}$ & ${ }^{-}{ }^{*} 3^{* * *}$ & .133 & $.251^{*}$ & 1 & & \\
\hline 7 & Satisfaction & 4.6655 & .63886 & $.275^{* *}$ & $\overline{-339}^{-}$ & $.357^{* *}$ & .032 & -.056 & $.265^{* * *}$ & 1 & \\
\hline 8 & Turnover & 3.1471 & 1.04133 & $.261^{* *}$ & $.495^{* *}$ & $\overline{-330}^{* *}$ & $.142^{*}$ & ${ }^{.178^{*}}$ & $.610^{* * *}$ & $\begin{array}{c}- \\
.360 * *\end{array}$ & 1 \\
\hline
\end{tabular}

*. Correlation is significant at the 0.05 level (2-

tailed).

**. Correlation is significant at the 0.01 level (2-tailed).

Table 3 displays the criteria to determine the level of employee perception toward work stress, job satisfaction, and turnover intention. Participants feel they experienced a little stress which classified as medium to low level (3.46). Regarding their satisfaction, participants reveal they are satisfied with their current job (4.67). They are also less likely to quit in the near future. They score 3.15 which is considered as medium to low intention to leave. In short, employees perceived satisfaction with their job, they do not experience uncontrollable stress and they have little intention to quit. 
Table 3. Perception Level for Work Stress, Job Satisfaction, and Turnover Intention

\begin{tabular}{cccc} 
& Satisfaction & Stress & Turnover \\
\hline Range & Category & Category & Category \\
\hline $1-1.83$ & Very dissatisfied & Very Low & Very Low \\
$1.83-2.67$ & Dissatisfied & Low & Low \\
$2.67-3.50$ & Tend to dissatisfied & Medium to Low & Medium to Low \\
$3.50-4.33$ & Tend to satisfied & Medium to High & Medium to High \\
$4.33-5.17$ & Satisfied & High & High \\
$5.17-6$ & Very Satisfied & Very High & Very High \\
\hline
\end{tabular}

Based on the regression results shown in Table 4, our hypotheses regarding the direct effect of each variable are supported. Hypothesis $\mathrm{H} 1$ that work stress has significant and negative effect on job satisfaction is supported (p-value <.01). Hypothesis $\mathrm{H} 2$ that work stress has significant and positive effect on turnover intention is also supported. And hypothesis $\mathrm{H} 3$ that job satisfaction has significant and negative effect on turnover intention, is also supported. All independent variables can predict the dependent variables.

Table 4. Regression Coefficient, Standard Error and Model Summary

\begin{tabular}{|c|c|c|c|c|c|c|}
\hline & \multicolumn{3}{|c|}{ Job Satisfaction } & \multicolumn{3}{|c|}{ Turnover intention } \\
\hline & Coeff & SE & p-value & Coeff & SE & p-value \\
\hline Work Stress & -0.200 & 0.049 & 0.000 & 0.681 & 0.067 & 0.000 \\
\hline Job Satisfaction & - & - & - & -0.348 & 0.089 & 0.000 \\
\hline \multirow[t]{4}{*}{ Constant } & 5.358 & 0.177 & 0.000 & 2.411 & 0.528 & 0.005 \\
\hline & \multicolumn{2}{|c|}{ R Square } & 0.070 & \multicolumn{2}{|c|}{ R Square } & 0.414 \\
\hline & \multicolumn{2}{|c|}{$\mathrm{F}=$} & 16.154 & \multicolumn{2}{|c|}{$\mathrm{F}=$} & 75.377 \\
\hline & \multicolumn{2}{|c|}{$\mathrm{p}=$} & 0.000 & \multicolumn{2}{|c|}{$\mathrm{p}=$} & 0.000 \\
\hline
\end{tabular}

The indirect effect of work stress on turnover intention which is mediated by job satisfaction is supported. Job satisfaction mediates the relationship. Table 5 show the bootstrapping results. Thus, $\mathrm{H} 4$ is supported (no 0 value between Boot-LLCI and Boot-ULCI). Job satisfaction has a contribution to reduce employee intention to leave.

Table 5. Indirect Effect of Job Satisfaction in the Relationship Between Work Stress and Turnover Intention

\begin{tabular}{lcccc}
\hline & Effect & Boot SE & BootLLCI & BootULCI \\
\hline Work Stress $\square$ Job Satisfaction $\square$ Turnover & 0.07 & 0.032 & 0.021 & 0.143 \\
\hline
\end{tabular}

\section{Discussion}

Our study reveals that the level of work stress is at medium to low as well as turnover intention. This means that workers perceive that their stress levels can be managed. Every job has its own risks regarding stress. In fact, without certain levels of stress, a job might be not interesting. In other words, they can cope with current work stress levels. Deadlines, various tasks, time concerns, conflict with co-workers or supervisors, are all conditions which happen frequently in any organization. Daily routines are exposed with such risk so that employees are already prepared to face them. If such conditions occur in the long term and increase the intensity, then employees might experience high stress levels. This is not happening in this study. Employees perceive the have a medium level of work stress.

Employees also have little thoughts to leave their current organization. Many factors can affect the intention to leave. External factors of turnover cannot be controlled. Instead, organizations need to focus on the internal factors including how to provide attractive jobs and rewards, develop organizational support, administer clear career opportunities, promote objective appraisal, and establish positive industrial relations. 
Employee who perceived that their organization cares for their well-being will reciprocate with loyalty. They are less likely to quit or even to consider the thought. There will be a great deal of advantages that they should sacrifice if they leave the organization. In reverse, if organizations do not have anything that can encourage employees to stay longer, they have nothing to lose if they leave. Organizational concerns regarding employee work life plays an important role to deter the intention to leave since it creates an attractive situation which might be available outside.

This cross-sectional study on Indonesian workers in Bandung provides several important findings related to job-related stress, satisfaction, and turnover intention. Work stress can predict job satisfaction and turnover intention. Regarding the effect of work stress on job satisfaction, our findings confirm the results from Chung et. al. (2017) and Lambert and Paoline III (2008) that work stress negatively affects job satisfaction. Employees with high levels of stress will experience a decrease in satisfaction. Stress that cannot be managed can become distress which reduces the level of satisfaction.

The current study identified the positive effect of work stress on turnover intention. This result is in line with research from Sheraz et. al. (2014) and Duraisingam et. al. (2009). Work stress is significantly associated with turnover intention whereas workers who reported to have high levels of stress develop high levels of turnover intention. On the contrary, Tziner et. al. (2015) found the mediation role of job satisfaction in work stress and turnover intention. Interestingly, work stress does not have a significant effect on turnover intention. This means that the causal effect of work stress on turnover intention still needs to be explored with various cultural backgrounds. The mediation of job satisfaction for work stress and turnover intention has been researched by Fried et. al. (2008) and Paille (2011). They found that job satisfaction mediates the relationship between work stress and employee turnover intention.

Our study suggests that organizations can use work stress and job satisfaction as predictors of turnover intention. It seems easy just to create less work stress and enhance job satisfaction. In reality, organizations face continuous challenges to balance those strategies. Business organizations need to be better which resulted in more pressure for employees. Thus, management should find a way to create a competitive environment that does not cause excessive stress to employees. They can start by improving selection criteria and focusing on individuals who are not prone to stress. This can help a lot since most stress is related with individual characteristics.

\section{Conclusion}

Various factors can affect the intention to quit. This research conducted an investigation into work stress and job satisfaction as antecedents to turnover intention. In conclusion, work stress has a direct negative impact on job satisfaction and a positive impact on turnover intention. Meanwhile, job satisfaction negatively affects turnover intention. Given the importance of employee turnover, organizations should always conduct routine surveys. They must also carry out human resource programs that can create a positive work environment such as providing clear career paths, providing training and development programs to prepare employees for future jobs, practice effective industrial relations, implement flexible work arrangements, provide challenging jobs, and practice the right leadership styles. Effective human resource practice can reduce stress levels. For example, if a company provides flexible hours, this may help employees to manage their work hours. Clear and fair career development systems also help employee to feel at ease because they do not have to worry about their future as long as they follow the provided career path. Opportunities to develop also play a vital role in reducing stress. Faced with intense competition, employees must be trained and developed properly. Failure to provide adequate training can affect job performance. With the reduction of stress, employees can better manage their life and work. The supportive environment makes them enjoy what they do and develop a higher job satisfaction. This feeling, according to the social exchange theory, will create a positive image of an organization. Employees who are more committed, engaged, and stay longer contribute more to the performance of the organization. 


\section{References}

Albrecht, S. L., \& Andreetta, M. (2011). The influence of empowering leadership, empowerment and engagement on affective commitment and turnover intentions in community health service workers. Leadership in health services. https://doi.org/10.1080/09585192.2017.1362660.

Ang, S. H., Bartram, T., McNeil, N., Leggat, S. G., \& Stanton, P. (2013). The effects of high-performance work systems on hospital employees' work attitudes and intention to leave: a multi-level and occupational group analysis. The International Journal of Human Resource Management, 24(16), 3086-3114. https://doi.org/10.1080/09585192.2013.775029.

Babakus, E., Yavas, U., \& Karatepe, O. M. (2008). The effects of job demands, job resources and intrinsic motivation on emotional exhaustion and turnover intentions: A study in the Turkish hotel industry. International Journal of Hospitality \& Tourism Administration, 9(4), 384-404. https://doi.org/10.1080/15256480802427339.

Boss, J. (2018). Employee Turnover Is The Highest It's Been In 10 Years. Here's What to Do About It. https://www.forbes.com/sites/jeffboss/2018/02/26/employee-turnover-is-the-highest-its-been-in-10-years-heres-whatto-do-about-it/\#de7c925478cc

Branham, L. (2012). The 7 hidden reasons employees leave: How to recognize the subtle signs and act before it's too late. Amacom. http://www.academia.edu/download/36971592/7_Hidden_Reasons_Employees_Leave.pdf

Cao, Z., Chen, J., \& Song, Y. (2013). Does Total Rewards Reduce the Core Employees' Turnover Intention? International Journal of Business and Management, 8(20), 62. https://doi.org/10.5539/ijbm.v8n20p62.

Chen, M. L., Su, Z. Y., Lo, C. L., Chiu, C. H., Hu, Y. H., \& Shieh, T. Y. (2014). An empirical study on the factors influencing the turnover intention of dentists in hospitals in Taiwan. Journal of Dental Sciences, 9(4), 332-344. https://doi.org/ 10.1016/j.jds.2013.01.003.

Chung, E. K., Jung, Y., \& Sohn, Y. W. (2017). A moderated mediation model of job stress, job satisfaction, and turnover intention for airport security screeners. Safety science, 98, 89-97. https://doi.org/10.1016/j.ssci.2017.06.005.

Demiral, Ö. (2018). Commuting Stress-Turnover Intention Relationship and the Mediating Role of Life Satisfaction: An Empirical Analysis of Turkish Employees. Social Sciences, 7(9), 147. https://doi.org/10.3390/socsci7090147 DuBrin, A.J. (2019). Fundamentals of Organizational Behavaior, 6th Edition. USA: Academic Media Solutions. Duraisingam, V., Pidd, K., \& Roche, A. M. (2009). The impact of work stress and job satisfaction on turnover intentions: A study of Australian specialist alcohol and other drug workers. Drugs: education, prevention and policy, 16(3), 217-231. https://doi.org/10.1080/09687630902876171

Elçi, M., Şener, İ., Aksoy, S., \& Alpkan, L. (2012). The impact of ethical leadership and leadership effectiveness on employees' turnover intention: The mediating role of work related stress. Procedia-Social and Behavioral Sciences, 58, 289-297. https://doi.org/10.1016/j.sbspro.2012.09.1003.

Fried, Y., Shirom, A., Gilboa, S., \& Cooper, C. L. (2008). The mediating effects of job satisfaction and propensity to leave on role stress-job performance relationships: Combining meta-analysis and structural equation modeling. International Journal of Stress Management, 15(4), 305. https://doi.org/10.1037/a0013932

Ghadi, M. Y., Fernando, M., \& Caputi, P. (2013). Transformational leadership and work engagement. Leadership \& Organization Development Journal. https://doi.org/10.1108/LODJ-10-2011-0110

Gibson, J.L., Ivancevich, J.M., Donnelly Jr., J.H., \& Konopaske, R. (2012). Organizations: Behavior, Structure, Processes, 14th edition. New York: McGraw-Hill.

Griffeth, R. W., Hom, P. W., \& Gaertner, S. (2000). A meta-analysis of antecedents and correlates of employee turnover: Update, moderator tests, and research implications for the next millennium. Journal of management, 26(3), 463-488. https://doi.org/10.1177/014920630002600305

Gyensare, M., Otoo, E., Asare, J., \& Twumasi, E. (2015). Antecedents and consequence of employee turnover intention: Empirical evidence from Ghana. Management Science Letters, 5(8), 781-796. DOI: 10.5267/j.ms1.2015.5.010 Hughes, L. W., Avey, J. B., \& Nixon, D. R. (2010). Relationships between leadership and followers' quitting intentions and job search behaviors. Journal of Leadership \& Organizational Studies, 17(4), 351-362. https://doi.org/10.1177/1548051809358698.

Hussain, T., \& Asif, S. (2012). Is employees' turnover intention driven by organizational commitment and perceived organizational support. Journal of quality and technology management, 8(2), 1-10. https://www.academia.edu/download/31543005/01-Is_Employees_Turnover_Intention_driven-

Dr_Tajammal_V_VIII_IssueII_Decem2012.pdf 
Jaramillo, F., Mulki, J. P., \& Solomon, P. (2006). The role of ethical climate on salesperson's role stress, job attitudes, turnover intention, and job performance. Journal of Personal Selling \& Sales Management, 26(3), $271-282$. https://doi.org/10.2753/PSS0885-3134260302.

Javed, M., Arsalan Khan, M., Yasir, M., Aamir, S., \& Ahmed, K. (2014). Effect of role conflict, work life balance and job stress on turnover intention: Evidence from Pakistan. Journal of Basic and Applied Scientific Research, ISSN, 20904304. http://www.academia.edu/download/51964181/Effect_of_Role_Conflict_Work_Life_Balanc20170228-7184ccawpx.pdf

Kaur, B., Mohindru, \& Pankaj. (2013). Antecedents of Turnover Intentions: A Literature Review. Global Journal of Management and Business Studies, Volume 3, Number $10 \quad$ (2013), 1219-1230. https://www.ripublication.com/gjmbs_spl/gjmbsv3n10_26.pdf

Lambert, E. G., \& Paoline, E. A. (2008). The influence of individual, job, and organizational characteristics on correctional staff job stress, job satisfaction, and organizational commitment. Criminal Justice Review, 33(4), 541-564. https://doi.org/10.1177/0734016808320694

Malik, M. I., Safwan, M. N., \& Sindhu, A. G. (2011). Examining stress, job satisfaction and customer satisfaction in a transport company (A case from Pakistan). International Journal of Business and Social Science, 2(18). http://www.ijbssnet.com/journals/Vol_2_No_18_October_2011/11.pdf

Mihelič, K. K. (2014). Work-family interface, job satisfaction and turnover intention. Baltic journal of management. https://doi.org/10.1108/BJM-09-2013-0141

Morneau Shepell (2018). Human Resources Trends for 2019 Insights on what HR leaders are expecting in the coming year: Summary report, October 2018.

Moynihan, D. P., \& Pandey, S. K. (2008). The ties that bind: Social networks, person-organization value fit, and turnover intention. Journal of public administration research and theory, 18(2), $205-227$. https://doi.org/10.1093/jopart/mum013

Nasra, M. A., \& Heilbrunn, S. (2016). Transformational leadership and organizational citizenship behavior in the Arab educational system in Israel: The impact of trust and job satisfaction. Educational Management Administration \& Leadership, 44(3), 380-396. https://doi.org/10.1177/1741143214549975

Oosthuizen, R. M., Coetzee, M., \& Munro, Z. (2016). Work-life balance, job satisfaction and turnover intention amongst information technology employees. Southern African Business Review, 20(1), 446-467. http://dx.doi.org/10.25159/1998-8125/6059

Paillé, P. (2011). Stressful work, citizenship behaviour and intention to leave the organization in a high turnover environment: examining the mediating role of job satisfaction. Journal of Management Research, 3(1), 1-14. https://doi.org/ 10.5296/jmr.v3i1.487

Park, T. Y., \& Shaw, J. D. (2013). Turnover rates and organizational performance: A meta-analysis. Journal of applied psychology, 98(2), 268. https://doi.org/10.1037/a0030723

Prasetio, A. P., Luturlean, B. S., \& Agathanisa, C. Examining Employee's Compensation Satisfaction and Work Stress in A Retail Company and Its Effect to Increase Employee Job Satisfaction. https://doi.org/10.5296/ijhrs.v9i2.14791

Preacher, K. J., Rucker, D. D., \& Hayes, A. F. (2007). Addressing moderated mediation hypotheses: Theory, methods, and prescriptions. Multivariate behavioral research, 42(1), 185-227. https://doi.org/10.1080/00273170701341316.

Robbins, S. P., \& Judge, T. A. (2005). Organizational Behavior, 15th. Shahrivar, $13,1393$. https://oldschoolbook.pythonanywhere.com/00-keyon-johnson-1/-organizational-behavior-12th-edition.pdf

Sang, K.J.C., Ison, S.G., \& Dainty, A.R.J. (2009). The job satisfaction of UK architects and relationships with work-life balance and turnover intentions. Engineering, Construction and Architectural Management, Vol. 16 No. 3, $288-300$. Sang, K. J., Ison, S. G., \& Dainty, A. R. (2009). The job satisfaction of UK architects and relationships with work-life balance and turnover intentions. Engineering, Construction and Architectural Management. https://doi.org/10.1108/09699980910951681

Scandura, T. A. (2017). Essentials of organizational behavior: An evidence-based approach. Sage publications.

Schermerhorn Jr, J. R., Osborn, R. N., Uhl-Bien, M., \& Hunt, J. G. (2012). Ohio University. Wayne State University, University of Nebraska, Texas Tech University.

Rizwan, M., Waseem, A., \& Bukhari, S. A. (2014). Antecedents of job stress and its impact on job performance and job satisfaction. International Journal of Learning \& Development, 4(2), 187-203. http://dx.doi.org/10.5296/ ijld.v4i2.6097

Siddiqui, A. A., \& Jamil, R. A. (2015). Antecedents of Employees' Turnover Intentions: Evidence from Private Educational Institutions. American Journal of Economics and Business Administration, 7(4), 160. https://doi.org/ 10.3844/ajebasp.2015.160.165 
Snell, S. \& Bohlander, G. (2013). Managing Human Resources, 16th Edition. USA: South-Western Cengage Learning. Terera, S. R., \& Ngirande, H. (2014). The impact of rewards on job satisfaction and employee retention. Mediterranean Journal of Social Sciences, 5(1), 481. https://doi.org/10.5901/mjss.2014.v5n1p481

Troesch, L. M., \& Bauer, C. E. (2017). Second career teachers: Job satisfaction, job stress, and the role of self-efficacy. Teaching and Teacher Education, 67, 389-398. http://dx.doi.org/10.1016/j.tate.2017.07.006.

Tziner, A., Rabenu, E., Radomski, R., \& Belkin, A. (2015). Work stress and turnover intentions among hospital physicians: The mediating role of burnout and work satisfaction. Revista de Psicología del Trabajo y de las Organizaciones, 31(3), 207-213. https://doi.org/10.1016/j.rpto.2015.05.001.

Venkataraman, P. S., \& Ganapathi, R. (2013). A Study of Job Stress on Job Satisfaction among the Employees of small Scale Industries. IOSR Journal of Business and Management (IOSR-JBM), 13(3), 18-22. http://iosrjournals.org/iosrjbm/papers/Vol13-issue3/C01331822.pdf.

Work Institute. (2018). 2018 Retention Report: Truth \& Trends in Turover.

Liao, C., \& Lee, C. (2009). An empirical study of employee job involvement and personality traits: The case of Taiwan. International Journal of Economics and Management, 3(1), 22-36. https://www.skillview.info/uploads/1/5/9/9/15997296/involment_and_pesonality_traits.pdf 